\title{
Keeping the Tradition of Honoring Ancestors (Study of the Traditions of Sadran Gedhe in Gumelem Village, Susukan, Banjarnegara)
}

\author{
Nurul Friskadewi \\ \{nurulfriskadewi@yahoo.com\} \\ Universitas Gadjah Mada, Faculty of Humanities, Indonesia
}

\begin{abstract}
Sadran Gedhe tradition is a form of joint prayer rituals intended to remember ancestors who have died and to avoid danger. However, slowly the traditions that place togetherness, tolerance, respect for the older are now attacked by individualistic attitudes brought by the current of globalization. This paper aims to examine how the tradition of Sadran Gedhe which embodied the values of local wisdom persisted, and its relevance to the development of local cultural resilience. This research uses ethnography with qualitative descriptive methods by conducting observations, and in-depth interviews. This study found that the tradition of Sadran Gedhe contains three aspects, namely the form of worship, pilgrimage, and alms which have socio-cultural, psychological and religious values contained in Javanese philosophy. It is also a cultural festival that strives to preserve local culture. It can reflect the concept of harmony for a better life while still adjusting the development of the times.
\end{abstract}

Keywords: harmony, Javanese culture, local wisdom value, Sadran Gedhe tradition.

\section{Introduction}

The incorporation of Western values that hitched the tide of globalization into the Indonesian community is a threat to the native culture that imaged the locality typical of the regions in the country. The release of lust and selfishness as an inner attitude of human beings becomes uncontrollable, becoming increasingly wild in the rhythm of moral degradation that once became the pride of Javanese people. The silting of the spiritual values of modern society is increasingly felt and tends to allow the exclusion of the elimination of traditional values, thereby shifting or even getting rid of the old paradigms of humans as social beings who are very polite in interacting with one another [1]. In such situations, mistakes in responding to globalization can result in the disappearance of local culture. Mistakes in formulating strategies to maintain the existence of local culture can also result in a local culture becoming increasingly abandoned by people who are now increasingly infatuated with the culture brought by the current of globalization. When the wave of globalization rolled over Indonesian territory, its strength was able to crush local cultures. Therefore, in the contemporary era, the biggest test faced by local culture is to maintain its existence amid globalization. At this point, the revitalization of the value of religious local wisdom in the tradition needs to be developed again. The problems faced by local culture in the past are far different than in the present. The ability of traditional societies to maintain their existence is a very difficult struggle. One tradition that still exists today is Sadran's tradition. In some places, Sadran's tradition has a different name such as Nyadran. In Sraturejo Bojonegoro and Loceret 
Nganjuk Sadran it is called alms of the earth [2], [3]. In Cikakak Banyumas it is called the Jaro Rajab ritual [4]. Whereas in Wonosobo it is known as Tenongan [5]. In Gambe Gemarang Ngawi Sadran tradition is called ruwatan or bersih desa (cleaning the village) [6], whereas, in Ngantru, Trenggalek is called clean dam [7]. In the hamlet Kepetingan, Sidoarjo Sadran also called nglarung sesaji [8].

In Temanggung, Sadran used to be popular with the name Sadran tuk Tempurung which was done to be an expression of gratitude for the abundant water for the community, especially Liangan Hamlet, Purbosari Village, Mudal Hamlet, and Kramat Tegalrejo District. The unique purpose of the sadranan is to make Sadranan ceremonies classified into several types. (a). Sadranan miwitan (miwit tandur) and Sadranan tobacco harvest, are ceremonies conducted to ask God Almighty that the planting season goes smoothly and varieties of planted species can be harvested with the best results. (B) Sadran merti hamlet or haul is a warning annual death of a person. (c). Sadranan Ruwah Sesaji by making a big cone where the material used at the top of the cone is depending on the yield. When the chili is being harvested, the material that is installed on the top of the cone is the chili. (d). Sadranan tuk Jumprit is done in a spring which according to myth, is believed to be a place that can solve a person's life problems or hopes [9].

Basically, the visit to the tomb is a Hindu religious tradition such as the worship of ancestral spirits, which until now, the burial place of figures known in history, or religious figures have developed into a destination for spiritual tourism [10]. Sadran is derived from the Sanskrit Shraddha, which means visiting ancestral graves to clean the tombs and sowing flower [11]. Sadran word also means salvation or offerings [12]. The perspective of Jamhari, Sadran is the second way that da'wah can be accepted, the ritual at the tombs of Muslim saints rather than at the mosque is to attract as many people as possible to attend the ritual so that they can increase their religious knowledge and practice [13].

The month of implementing Sadran's tradition varies from region to region, some are held in the month of Shuro (Muharram) or Shafar, some are Rejeb, and the most in the month of Ruwah (Sya'ban). In Ngepringan Sadran implemented after the harvest as a form of expression of gratitude, before the month of fasting (Sha'ban) or in the month of Suro [14]. Nganjuk Sadran tradition is held in the Sha'ban month (in the Hijri calendar), which is between the 15th and nearing the month of Ramadan [3]. In Bajulan Village, Loceret District, Nganjuk Regency, Sadran ceremonies are usually held at the tomb [3]. In Sukoharjo, pilgrims visit the tomb of Ki Ageng Majasto (KAM) for several special days. On the night of Tuesday and Friday, in the mid- month of Ruwah / Sya'ban month (at Sadran ceremony) or at 1st Suro (Muharram) [15]. In Wonosobo, Giyanti Hamlet, Kadipaten Village, Selomerto Subdistrict, Sadran was only held in the month of Muharram or the month of Suro. [5]. The Jaro Rajab tradition or grave pilgrimage, in the Cikakak community, is held every 26th of Rajab as a symbol of respect to Kiai Mustolih who spread Islam in the 17 th century AD [7], [16]. The Jaro Rajab tradition or grave pilgrimage, in the Cikakak community, is held every 26th of Rajab as a symbol of respect to Kiai Mustolih who spread Islam in the 17th century AD [4].

One of the goals of Tradisi Sadran is to obtain the blessing, which each differ in interpreting [13]. According to his, berkah means the success or worldly blessing (mundane qualities) and a blessing in the form of contentment with the provision of reward from Allah (transcendental qualities). The purpose of holding Sadran in Bojonegoro is, first, to express gratitude to Allah SWT for the favors given to the community with abundant harvests. Secondly, to respect the ancestors who have been instrumental in opening land (tripe mat) as a place to inhabit the community as well as a place to find life. Third, the implementation of Sadran can strengthen solidarity between people with one another. Fourth, the preservation of 
native cultures. The benefit that has been obtained by the people of Sraturejo by holding the Sadran tradition is that the community feels a sense of being closer to the Creator, far from disturbances (bala) and disease, better yields [2].

According to Jamhari the purpose of Sadran is (1) To achieve closeness with God (2) for the salvation of life in this world and life in the hereafter (3) for happiness and prosperity in living in this world (4) to remove sin (5) to obtain shafa'at from the Prophet Muhammad (6) as protection from jin and devils (7) as protection from magic and sorcery (8) to facilitate all businesses (9) to facilitate all needs (10) to make all businesses successful (agriculture, trade, agriculture, animal husbandry, and industry) (11) to facilitate the means of living (sustenance) (12) to build a peaceful and harmonious family (sakinah family) [13].

Sadran is usually carried out through a ceremonial procession, using offerings or ubarampe as was done in Kedunglo Village, Kemiri District, Purworejo and Getasan District, Semarang. Tumpeng, symbolizes a hope to God so that the wish will be granted; Ingkung (chicken cooked whole) symbolizes humans when they were babies have not had any mistakes; plantain symbolizes a hope that one day a happy life; the snack market symbolizes God's blessing; sticky rice, compote, and apem, is a unity that means a request for forgiveness if you make a mistake; incense is a means of petition when praying; and flowers, symbolizing the fragrance of prayer that comes from a sincere heart. These various "innate" elements are offerings as a basis for prayer. After praying, these foods became a struggle for the pilgrims present. This is the meaning of togetherness in sadran. When the community implements sadran, they must work together [17], [18].

In Trenggalek, there is a Sadran ritual performed by bathing a buffalo before the buffalo is slaughtered [7]. Sadran is usually done at Bagong Dam, not at the tomb. Bagong Dam is a Bagong river divider dam which is commonly used to irrigate rice fields in Trenggalek City. During the Sadran Dam Bagong ceremony, a buffalo was sacrificed and then slaughtered and the head, skin and bones were thrown into the river and then fought over by the local community members. [16]. In Sidoarjo, the majority of people who work as fishermen and fish farmers do Sadran (Nglarung Sesaji) so that the blessings from fishing and raising fish still reap the benefits to meet their daily needs. In the ritual, before praying, there are prayers and mantras as well as several conversations from community leaders and also reciting special mantras in the form of singing poems. [8]. In Giyanti, Sadran performed by displaying various traditional arts of its citizens aimed at promoting the tourist village in Wonosobo Regency [5]. In Semarang, the Sadran tradition is complemented by carrying out the padusan after the Sadran series is finished. Padusan comes from Javanese, which is adus (bath). Padusan is a bathing activity (clean oneself), which has the meaning of physical and spiritual preparation for the month of Ramadan [17].

The procession of Sadran's cultural traditions in Kromengan, Malang is as follows: 1. Community Service (Clean Village) Sadran's cultural demand for the first time is doing community service activities, this activity is carried out by all residents of Kromengan Village. Community service activities carried out by residents in various areas include cleaning up graves, village roads, both the main road and rice fields and channels in the village environment. This activity is mostly carried out by fathers and teenage children, the mothers only prepare food and drinks which are placed in the yard close to the fence of the house. Clean village activities (community service) are carried out to create a village environment that is beautifully clean and neat, togetherness is felt when the activity takes place [19]. Also, activities were carried out in the village hall. This activity was followed by the community of artists in the form of reog, kuda lumping, as well as groups of farmers and herbalist producers and also students ranging from kindergarten to high school, community, RT / RW 
representatives and village officials. The closure of the village carnival was followed by the gathering of village officials and community leaders to recite Javanese songs together with the sinden who were appointed and then ended with a shadow puppet performance all night long. The implementation of Sadran in Sraturejo Bojonegoro was also accompanied by the appearance of existing regional cultural arts, such as gamelan music, dance (tayuban), and wayang performances. [2].

Through this procedure, it is not surprising that there are differences of opinion among the people who hold fast according to Islamic teachings regarding the pilgrimage law. It is feared that pilgrims ask the deceased. Also, some concerns existing devices will cause polytheism [20]. In Ngawi, Sadran's tradition is accompanied by drinking palm wine, ledhek (dancer). For those who get drunk, they get an award from the village head because of the totality in implementing sadran as a participant. The personalities of the Jambe people prioritize the aspects of self-emotion, especially the peak achievement of the sadran ritual in the practice of drinking wine, the people of Jambe Gemarang call it to play. The play means reaching the top of the sadran. While the ledhek dish is done after a wine drink and usually the dancer is given a saweran [6].

Among 'modernist' Indonesian Muslims, the practice was considered not only as an inappropriate addition to religious rituals but also as a serious violation of Islamic teachings that led to polytheism (shirk) because people might mistakenly ask for something directly from the person who died. Another serious violation is Sadran's tradition invites ugliness (disobedience) [13]. Many responded to Sadran's tradition from various perspectives. Some think this tradition is a form of gratitude to Allah for the various fortune received by residents for one year and hopes that fortune is abundant next year. Others think the show is just a form of rah-rah which is packaged in a religious ritual that has no educational value. There are even those who argue that Sadran in Giyanti is nothing more than an idolatry ceremony which is legalized in the frame of a tourism package. Regardless of the various assessments from each perspective, there must be a lot of wisdom and benefit from each event, but the wisdom and benefits that we have not been able to express. Various parties only see a tradition from their perspective without seeing the actual reality or are unable to understand it from another perspective [5].

With a syncretic character, at least Sadran's tradition has pros and cons among the people. As stated by Daryono, one of the heretics that arises and includes two worship services, is about commemorating the death and sending the prayers of the deceased [20]. In social worship, sadran is unity with two Javanese moral norms namely, respect and harmony. These two moral norms, on the one hand, have strong demands that are always lived by every Javanese.

Sadran tradition contains cultural syncretism which then produces a new tradition. Many people gather to visit the tombs and then they pray for the deceased ancestor with what is called dhikr namely Tahlil, prayer beads, tahmid, and tagfir. Many activities are carried out together with dhikr, namely: burning incense, putting flowers in a glass, etc. Where all the above ceremonies are from Hinduism [21].

The acculturation of Islamic and Javanese culture is reflected in the lives of the people of Krajan, Malang. The use of Javanese / Islamic calendars in every cultural activity is still used [19]. In Cikakak Banyumas, the Aboge Islamic community still uses and practices the Javanese calendar. Aboge stands for Alif ReboWage, which is education used by Aboge followers to determine the date, month, and year as the Hijri Calendar or Gregorian calendar. The basis for determining the Aboge calendar is trusted by the community with the count of Windu (eight years) by mentioning the terms alif, ha ', initial jim, za, dal, ba, wawu, and jim 
[4]. Aside from the calendar, acculturation can also be seen in the festivity, which is an objectification of two religious traditions namely, from Muslims and Hindu traditions. [14].

Sadran's tradition of social life, nature, and aspects of worship to God as conveyed by Ibda [22] there are (1) Syauq (missing): by doing sadran means loving God, humans, and nature as a form of an obedient servant. (2). tarkus lust is holding back lust. (3). muhasabatun nafs: self-introspection, (4). at-taubah: repentance (5). zuhud: ukhrawi / asceticism orientation, (6). al arif: the value of wisdom (7). al iffah: maintain purity (8). al syaja'ah: the courage to guard religion and state. (9) al adl, that is, doing justice to God, humans, and nature, through the awareness of the community will remember God, share with humans through food, share with guardians, kiai, or heroes who have died through prayer / tahlilan, and share with nature through prayer. These values are a form of local wisdom that should be maintained.

The values of local wisdom are not obsolete values that are obsolete so that they are abandoned, but they can synergize with universal values and modern values brought by globalization. With the actualization of the cultural philosophy of 'hamemayu hayuning bawana' which teaches people to behave and behave that always prioritizes harmony, harmony, harmony and balance of relations between humans and nature, humans and humans and humans and God in carrying out life and life so that the country will be "panjang punjung, gemah ripah loh jinawi, karta tur raharja " [23]. Local wisdom expressed as a lump of meaning in which there are webs of meaning and millions and even billions of meanings [24]. So, local wisdom is also like a well, it will not be drained of meaning, even in the dry season. Local wisdom can be interpreted anything, according to context and needs. Local wisdom refers to the aspect of reasoning which means wise. Local wisdom is a tradition celebrated by a group of people to carry out a tradition, thus it is one form of local wisdom. It can be interpreted that local wisdom is a tool, knowledge and practices that can be used to solve problems faced in a good and right way according to society [25]. The tradition in the community will realize local wisdom values that sometimes encountered in urban society today. Horizontal and vertical relationships in rural communities manifested because of the full conviction that human life is interconnected with one another.

Memorial about death is considered as a form of respect for ancestors. From this, they believed that the spirits of the ancestors were still related to their families. So, to welcome his presence a salvation activity event was held (praying together to save the world and the hereafter). Based on the conducted show that the actualization of Sadran's traditional values is local wisdom [26]. But the values of sublime local wisdom will eventually erode. Therefore it must remain preserved. Based on the explanation above, it can be concluded that Sadran is almost carried out throughout Java with the same principle, namely respect for ancestors. Each region has its terms and manner of implementation as a pointer to interests. Regarding the implementation time, almost all studies agree that the time taken is the same. Some aspects that have not been studied in Sadran's existing research are seeing Sadran's practice by connecting the meaning contained in it. Also, as a tradition that grows and develops in Java, Sadran has not been associated with the interpretation of Javanese society. Therefore this paper will focus on these two things to complete the puzzle in the unity of the Sadran tradition. As expected, the purpose of this paper is to examine how the tradition of Sadran Gedhe which embodied the values of local wisdom persisted, and its relevance to the development of local cultural resilience. 


\section{Research Method}

This research uses ethnography with a qualitative descriptive method. It describes Sadran culture. Therefore the data collection process was conducted by interviews with informants who were involved in Sadran's tradition and important figures who influenced the course of Sadran Gedhe. In addition to interviews, data collection techniques were conducted by observation and documentation of the implementation of Sadran. Data analysis uses technique is intended to make the data that has been obtained by the Gumelem village who follow Sadran, the process of implementation of Sadran tradition, and books related to Sadran. The form of data in this study is a description of the purpose of holding sadran and religious values in sadran.This research uses field research that is trying to enter and learn in the world of others to directly learn about their cultural life [27]. In addition to witnessing Sadran's tradition on a predetermined day, living with the community becomes important to know the culture, the values they profess.

\section{Results and Discussion}

The Sadran tradition in Gumelem, Susukan Subdistrict, Banjarnegara Regency has become special in terms of the procession because it has a relationship with the Islamic Mataram Kingdom and has serious attention to the preservation of Javanese culture. the grave of Ki Ageng Girilangan is believed to be a place of prayer to be granted. People who have an interest usually carry rice cone which is filled with wader (kind of small fish) mixed with grated coconut and supplemented with papaya, fried noodles. The food is believed to be the favorite food of Ki Ageng Gumelem (the founder of the village). or facilities as a medium for the purpose to be granted. Met by Mr. Ahmad Sujari, that visitors who come usually have a purpose, such as wanting a position (Candidate), want to live more prosperously, or when there are problems. There are also residents of Gumelem who do prayers at the grave of Ki Ageng Girilangan because it is the advice of the clerics because he is undergoing treatment. This is also believed by people outside Gumelem (from outside the city) and developed by word of mouth. Even so, Mr. Sujari always stressed that to pray is still addressed to Allah SWT, not to ask those who have died. Guests will usually contact Mr. Sujari, and guests will be escorted. Not only during the day, sometimes guests come at night or even early in the morning. Judges are advised to come on Monday or Thursday because on that day the caretaker always comes along with the tomb cleaners. Also, it is said that the story on Monday and Thursday, is a special day because in ancient times Monday and Thursday especially wage (Javanese day) is a grand renting day, the gathering of trustees (interview: Tumyati (84 years), on April 10, 2019). The hope is that if people pray on that day, then the prayer will be answered quickly and witnessed by those who have power (Javanese: keseksen karo sing mbau rekso). Until now, people believe and usually, they are pilgrimages and hold Sadran traditions on Monday or Thursday.

The Sadran series, which is a tomb clean, is done about 1 week before fasting. This activity is called gethekan. This ritual is carried out after getting a notice from the smelly father (village official) and the caretaker. Usually done after the harvest period is over. The women usually carry tenggok (a rather large plaited place, how to carry it carried) containing cone rice which includes salted fish mixed with coconut pulp, and fried noodles and dried tempeh, and crackers. Also, they also carry interest and money. After arriving at the tomb, 
tenggok is placed in Paseban, then they clean the tomb, usually, their husbands have come first to clean the tomb. All residents worked together to clean the tomb (especially men) and women clean the environment. After finishing, they then prayed for the family's grave by ending sowing flowers and immediately heading to Paseban.

The key clerk will give a speech, and briefly then invite anyone who wishes to pray at the grave of Ki Ageng Gumelem. Collections of flowers collected and money taken to Ki Ageng Gumelem's tomb cupola and began to pray. Prayers are offered to God and a series of names are called Sheikh 'Abdul Qadir Jailani, Kyai Ageng Giring, Kyai Gumelem, Kyai Singakerti, Mbah Kyai Prigi, Kyai Nur Daiman, Mbah Sangu Banyu, Mbah Cakrajaya) and the ancestors of Gumelem. They are the ones who are considered to be the rumors of all aspects of the life of the Gumelem community and its surroundings, therefore prayer is also sent to them.

After the reading of the prayer and request was finished, the caretaker along with the pilgrims who entered the grave of Ki Ageng Gumelem then sat back to Paseban. Interest and money are brought back to Paseban. The key clerk, Pak Ahmad Sujari then started the prayer and tahlil back just like praying inside. After finishing, with the sitting position lesehan facing each other elongated, in front of them lay rice and then enjoy the existing tumpeng rice. The way to eat is usually called a siege. Uniquely, cone rice that is eaten and taken home is not a self-cooked rice cone. Besides being followed by residents living in the hamlet in question, Gethekan was also followed by hamlet residents who lived outside but had ancestors buried in the hamlet.

The Sadran tradition in Gumelem is often called Sadran Gedhe (in Javanese Gedhe means big). That night, Saturday 27 April 2019 at 8:00 p.m. has held the opening of the series of events of the Sadran Gedhe Tradition. The road to the Paseban Girilangan Cemetery has been packed with residents who will attend tahlil qubro big). This year 2019 seems different. On the wall, the stage reads Paseban Syafaat, while below it is a smaller size with an Old Javanese letter that reads "Damparing arga murcaning jalmi". Some people are found as security guards. The Paseban page is filled with motorbikes. Sholawat using modern music is offered to worshipers. Right at 10:00 p.m., Kyai Mbah Tithut and Gumelem Kulon and Gumelem Wetan were present. In the event, the theme is a juguran (Indonesian sits together). Some people wear black clothes originating from Pakem (Association of Friends of Mataram). In the series of events, at the same time as the opening ceremony of Sadran Gedhe. The activity continued the next day with various competitions namely, batik design competition, writing the history of Gumelem, Kakang Mbekayu's audition. The contestants came from elementary school for batik design competitions, junior high school to audition behind the background and write the history of Gumelem, as well as high school students to audition behind Mbakayu. The competition was intended to introduce Gumelem culture to children as the next generation.

Before the peak of the carnival event, people usually enjoy traditional art entertainment. The next day was followed by an ebeg art performance which was played by 4 women and 4 men. That afternoon, the weather was very hot. After the dhuhr prayer, the Banyumasan-style gamelan sounded loud. People flock to the origin of the sound. The ebeg dancer is complete with costumes and his lumping horse has begun to dance. Sunlight does not seem to relax the intention of the audience because more and more spectators are coming. Around 3:00 p.m. dhalang prepared the equipment and chanted a mantra. Shortly thereafter, one of the dancers was in a trance. The atmosphere became somewhat tense. Shortly after that, some people were possessed, and up to about 15 people. The atmosphere became increasingly tense. One by one 
the dhalang heals, aided by "smart people". The event ended approximately until 17:00 with the audience already unconscious.

The series of Sadran events that day were not over yet, at night at around 8:00 a.m. the program began again, lengger lanang art performance. Along the way to the throne, the members of Pakem (Paguyuban Kerabat Mataram) have been lined up. The road is for guests. That night was special because it was attended by the family of the Sultanate of Surakarta, Pakualam Jogjakarta, the Sultanate of Cirebon, the Sultanate of Demak and the officials of the Bedono hamlet, Kab. Jepara. Whereas the viewers passed another road and sat on the lawn. In the event themed Gumelem Culture Ritual, there is also a graduation ceremony for Pakem members. The peak event began, even tall, thin male dancers began dancing like Gatotkaca accompanied by gamelan. This magical ritual may be similar to magic tricks. After the dhalang recites the mantra and touches the dancer. A mighty dancer who is instantly weak and sits, dhalang even binds his hands and body so he can't move. In front of him, a woman's kebaya shirt is provided, along with a kemben, slides (headgear to dance) and sampur in a box. Dhalang was close to the dancer with a cage. Accompanied by gamelan and sintren-themed songs, the mouth of dhalang mutters the mantra. After the cage moves, the dhalang opens. Men tied up turn into beautiful women and smell nice. The audience was even more curious when the man walked with a box. According to them, the money given will bring blessings.

In the morning, Sadran's top of event began. People are busy preparing themselves. Each group gathered to get ready to march. The community was packed along the Gumelem Wetan village hall road. Meanwhile, in front of the gate of Kademangan, two people were busy arranging ancak as treats for the residents. The guests of the family of the Sultanate of Surakarta, Pakualam Jogjakarta, the Sultanate of Cirebon, the Sultanate of Demak and the officials of the Bedono hamlet district. Jepara gathered at Gumelem Wetan Village Hall. Village officials wear typical Gumelem clothes, along with Pakem members, who wear black tops and subordinates in the form of jarik (batik cloth). While some people were carrying a spear. At the beginning of the line, there were two people carrying incense. The Frankincense will be placed on the graves of Ki Ageng Giring and Ki Ageng Gumelem. The offerings are intended for safety. In Javanese religion always outlines the function of offerings as 1) the step of spiritual negotiation with supernatural powers, so as not to disturb, 2) giving blessings to the local people, so that they feel the offerings, 3) manifesting self-sincerity, sacrificing to Kang Gawe Urip, offering is a form thanksgiving [28].

Before the caravan began, it began with the giving of sticks and ties from the Sultanate of Cirebon to Mr. Agus WInaryanto as the person in charge of the event. While on the road, the Kirab participants "' 'Babad Dalan Giring' were ready. The first row was occupied by the royal families who were riding a horse-drawn carriage, behind which village officials included the village head Gumelem Kulon and Gumelem Wetan Kakang Mbakayu Banjarnegara. Next is the ranks of the Pakembara (Paguyuban Kerabat Mataram Banjarnegara), followed by a line of Shalawat who bring tambourines, as well as drums. Behind. The women carry rinjing containing cone rice and side dishes. Some women carry tenongs, containing food for salvation. Next is the sugar-making women along with the men penderes (taking nira water). Behind him was a car filled with sugar arranged like a cone weighing $80 \mathrm{~kg}$. Arriving at the entrance gate was greeted by the words "Sadran Gedhe Goemelem 2019". The palace guests descended from the horse-drawn carriage in front of the Paseban and walked towards the throne that had been provided, while the group of village heads went up to Ki Ageng Giring's tomb. In the grave of Ki Ageng Giring, dhikr and prayer are performed together. The hot weather did not thrill the souls of the carnival participants. However, unfortunately after arriving in Paseban the rain fell profusely. Village officials who descended from Ki Ageng 
Girilangan's tomb walked on wet rocks. They continued to go to Ki Ageng Gumelem's grave to say a prayer.

Village officials, district officials and the House of Representatives then sat in Paseban which was equipped with a row of food. Pikulan is in the front row which contains a turret, ambeng menir, golong menir, ambeng menir, ambeng intip, ambeng beras ketan dwi warna, pecel ayam cemani, cramcam terong aor, sayur bening daun kelor, tempe goreng adem, peyek pethek, pendul made from meat mixed with young coconut pulp, young coconut is given a hole filled with coconut sugar and cokbang. Tenong which contains rice golong, fried noodles, fried tempeh, crackers, chicken, and fried sambal are in the next row to the back.

The tenong brought by the women was placed in Paseban. While the community was abuzz doing the ritual "Nyadong Berkah Bumi Gumelem Blabur Gula", namely the process of blabur (over), sugar began. Gumelem has indeed been a producer of sugar from sap. These products as a sign of gratitude for what they have received. The program continued with the symbolic surrender of the will key. After that, the Cirebon Sultanate king gave a speech that began with gratitude and prayer, then honored the guests present, and at the core of the Sadran tradition that the tradition would bring blessings to the people of Gumelem. Beyond that, he also said that this tradition has the potential to become a place for cultural tourism. After completion, the program continued at a glance with Italian calung music. The royal families remained on the throne, while village officials, were in Paseban. While other guests and spectators have provided a place and eat using ancak (talam; woven made from bamboo which has a rather tenuous distance when compared to besek). In the ancak, food is provided the same as in the Tenong.

There are still more treats, namely the Ujungan dance which is a regional dance. Where the dance is a condition of meaning. By using rattan wood on the right, and the protective hand on the left. Wearing a typical hat of Ujungan dance, and the knee to the soles of the feet must be shown because of being hit. With the end of the Ujungan dance, Sadran Gedhe Gumelem ended.

Based on the description above it can be concluded that the Sadran tradition in Gumelem at least has the following basic elements: (1). pilgrimage / nyekar, (2). alms, (3) worship. From these main elements, values can be taken as follows: (1) religious value, (2). cultural values, (3). social value, (4). psychological value.

In general, Javanese people recognize that there are other forces beyond their strength. This was confirmed by Ningsih that since Java still adheres to barism, they do not know civilization, in fact, they have recognized it [29]. This power is none other than the occult of the universe [30]. They assume that if they can negotiate with other forces, their lives will be helped by the universe. Conversely, if they fail to negotiate, it will be bad too. They believe that the universe is also in him.

\subsection{Through the Sadran tradition, there are at least some basic elements as follows:।}

\subsubsection{Pilgrimage / nyekar}

Sending the prayers of the deceased by coming directly to the grave called Sadran, there is a name called nyekar or grave pilgrimage. This, done to remember that this self will follow death. Also, pray for the deceased to be forgiven of his sins. Aside from being done in a cemetery, Sadran's tradition can be done in other places, for example in research in Kromengan Village, Malang where Sadran is conducted in three places, the first at the village punden, the second at the tomb of the village head's parents when his parents have died, and the last clan at the water source that first drains water to the village where it lives [19]. Some 
ubarampe prepared by some people in the procession of pilgrimages among other incense and various kinds of flowers typical of Indonesia, such as roses, jasmine, and kenanga (Warsiyem, 56 years).

\subsubsection{Worship/ sadran prayer}

The aims of Sadran tradition in Gumelem is as a means of worship and reassuring the soul and peace in the heart for those who hold the tradition of Sadran. Sadran activities carried out with a pilgrimage to the ancestral tomb or influential figures in broadcasting Islam in the past. As well as Gumelem people implement Sadran in the grave punden Ki Ageng Giring and Ki Ageng Gumelem as kyai spreaders of Islam. Daryono said that Sadran was one of the Javanese Islamic cultures as a form of ritual prayers and alms of various kinds of food that were carried out in a funeral complex (cemetery) [20]. Prayers are carried out by people who have family members who have died together sending prayers by reciting yasin-tahlil is expected so that the spirits of each of the ancestors can be accepted by Allah swt forgiven his sins and put into his peaceful heaven or happiness. Sadran is a form of respect, awards, and worship (birul walidain) to the ancestors embodied in the form of blossoming and praying for the good life. There is the Sadran Prayer more or less means that in prayer sadran re-present events that are believed to exist in the past, both about the power of gods, prophets, supernatural kings and the knights. If observed carefully, the meaning of evoking can mean sending or communicating prayers to spirits. Components of opening greetings that read please multiply the greetings. Based on these phenomena then this prayer gets influence or touch of Islam in the expression of greeting should sound Sallalahu alayhi wassalam. This phenomenon shows the existence of a combination of Javanese and Islamic culture. In addition, the sound change is also commonplace or prevalent in society, it is merely to simplify the pronunciation like "alaihi wasalam" said "ngalaihi wassalam". Another word that experiences grammatical aberrations is bismillah to be semilah. Although they are still wrong in pronunciation their first intention of implementing Sadran is aimed at Allah SWT then Prophet Muhammad and his family and friends. Arabic Java is a symbiotic mutualism between Arabic and Javanese.

Also to tahlilan, also known as praise is the activity of singing songs to praise God or praise (praise) to the Prophet. In this case, Yulianingsih, explained the purpose of praise, namely, (1) praising the glory of God, (2) praying to God, (3) prayer and repentance to God, (4) asking safaat to Rasulullah, (5) advising people to do worship and good deeds and away from disobedience, and (6) teaches about religions such as faith, pillars of Islam, jurisprudence, morals, texts, Qur'anic commentaries, and sorof.

\subsubsection{Alms}

After completing yasin-tahlil continued eating together at the graveyard by feeling each other's food, by exchanging one cone with another then brought home as a blessing (blessing food prayers). At Somagawe Semarang mangan (famous) [17]; in this tradition it is called selametan or kenduren [14]. Or almost most mentioned salvation [31]. This alms aims at expressing gratitude to God Almighty which is manifested in the party of the people after the harvest. The Gumelem people are grateful for the fortune that God has given for a year, and hope that the next years harvest will be more abundant because the Gumelem people mostly grow crops. 


\subsection{In practice the three main elements are created by several activities that support the Sadran tradition such as art performances, and socio-cultural activities that contain the following values.}

Flowed from Yuliningsih [17] said that the community's view of Sadran's tradition was an expression of social-religious reflection that gave religious teaching. In the verse, Allah SWT forbids humans to do damage on earth, but to pray to be a good person, because God's grace is close to the people who do good deed. The guidance for human beings to be grateful for the blessings of God is given to them, in the fertile soil will grow good crops, whereas barren land will not grow crops but suffers. That is a sign of the greatness of Allah SWT. Islamic values contained in the tradition sadran not separated from the values of Javanese culture. Although there are strict limits when praying, you must be sure that the God who will grant is not someone who has died. In addition, worship aims to get closer to Allah and pray for the deceased elderly and relatives. The implementation of Sadran blends with the event of prayer and praise.

In the present time tahlilan is used as a term for association of people to pray together for the dead, where the tahlil reading becomes the core of the reading. Tahlil means reading the sentence la ilaha illallah. not to spirits (jinn, shaitan, and so on). People believe that the gate lock to heaven is the saying tahlil. But in fact, people who make a pilgrimage to the grave are strongly encouraged to reproduce the dzikir reading and the peak on the tahlil reading. Besides that, in terms of sedekah is meant to our prophet Muhammad Saw who has shown the appropriate path for his people, so this sodakohan is also called Rasullan which means to manifest the sense of love to Rasullulah.

\subsubsection{Cultural values:}

It is in this context the importance of preserving that tradition, as it grows in society itself. It is usually closely related to the natural resources and living conditions of the local area. As it is said that visiting the tombs of the ancestors as a form of preservation of the cultural and cultural heritage of the ancestors [17]. In addition, Sadran's tradition has been created with local culture such as Gumelem. Sadran in Gumelem was enlivened by the typical art performances of the region including ebeg, lengger lanang, etc. This also happened in Wonosobo, Sadran was enlivened by the Lengger, Sontoloyo, Rangu-rangu, and Rampak Buto dances to accompany the ritual [5]. Participants in the ritual procession in Gumelem wear complete Javanese traditional clothing. That way can introduce and maintain local culture materially.

\subsubsection{Cosmic Value}

The cosmic wisdom value of human relations with the Creator is manifested in the performing arts which become a series in the tradition of Sadran Gedhe Gumelem. The show has the main meaning that is as gratitude and asking the Almighty God so that all villagers get barakah, kept away from various disturbances, granted all the villagers' desires, as well as all the village's waiting spirits, forerunner, feel happy so as to add excitement to work hard and business success. Cultural attractions that emerged include the group sholawat who are members of the carnival row, the Pakem group which in part brings offerings, calung performances that are equipped with offerings, and as a prohibition are puppet shows. This is part of the symbolic meaning of the Javanese religion. 


\subsubsection{Social Value}

The social value of the traditions of Sadran is associated with the maintenance of the memory so as not to forget its origins by way of grave and pilgrimage blooms. The Javanese ancestor had a wise statement: manungsa wrote lali wetone. At first elinga marang wong tuwa senajan wis padha swarga which means human beings should not forget the day of birth, so remember the old people even if it is in heaven. According to the Javanese context, the social value of the sadran tradition is associated with the preservation of the memory so as not to forget its origin by the grave and the pilgrimage blossoming [32].

In the social life of traditions sadran has outlined the principles of local traditions and teachings of Islam. Praying together it also can strengthen the relationship of brotherhood among Muslims called ukhuwah Islamiyah. The values of these principles are ukhuwah, compassion, help, amar ma'ruf nahi munkar and the similarity that every human will surely return to the Khaliq (God) and the gratitude to the God.

In one of Sadran's traditional activities, Gethekan It is like sambatan (cleaning the environment together). Sadran transformed into a gathering event [17]. Based on his research, Satria said that 5 different religions carried out the Sadran tradition, with the implementation being arranged in consultation, and carried out cooperatively by all residents of Gejayan, Sleman [33]. Likewise ,Riyadi's research results in Kayen Village, Jemangi District, Boyolali Regency. An important finding in this research is that Sadran's tradition is an expression of social piety through the practice of cooperation, solidarity, and togetherness. Sadran can be a medium of accommodation and a medium for developing harmony between people, especially in diverse and multicultural societies. The tradition in the village of Kayen with its various procedures has been able to develop the primordial bonds of its people in a group that has the same beliefs and views despite different religions and beliefs [34].

\subsubsection{Psychological value}

In Sadran's tradition in Gumelem, it contains a psychological value, for example to clean the tomb done before Sadran begins which means to cleanse oneself before facing God. Uborampe is like pouring water over ancestral graves, sowing flowers, and "incense" fragrances, laying chicken eggs, then reciting prayers meaningfully so that prayers are answered along with incense fragrances and always get good. This has a positive impact on Sadran's perpetrators. Also, human relations with animals and the natural environment are taken from the tradition of Sadran community brought all forms of crops such as rice in the form of cone and vegetables and a side dish of ellen chicken which all have the philosophical value that humans must always worship God and have high hopes [14].

Local culture and tradition as a representation of local knowledge or local wisdom that functionally becomes a means of accommodation to maintain a harmonious environmental situation, including social relations in interfaith life and even across cultures. One of the values of local wisdom in the community is the Sadran ritual tradition. In Sadran, there is also the core of Javanese culture that is harmony. The Javanese people not only expect harmony in human relationships but also with the universe, even with supernatural spirits. Therefore offerings are given not intended to worship the supernatural spirits but to create harmony with the whole of nature. Meals, incense, and flowers have symbolic meanings.

Looking at the description above, the structural functionalism approach can still be drawn in this theme. Although this approach has long been found, it is still relevant to use in this paper. The functional approach sees the integration of community members with certain values. Society as a particular social system is functionally integrated into a form of equilibrium. Durkheim gave priority to his analysis in a holistic society where parts or 
components of a system functioned to meet the main needs of the system as a whole. [35]. In this perspective, society as a system that is interconnected between one another and which is reciprocal and symbiotic mutualism. Likewise, if implemented in the Sadran tradition, integrated society is caused by one common need. There is no longer any class, religion or pros and cons, all merging into one. This goes in tune according to the value of Java which tends to reduce the conflict so that life is in harmony.

\section{Conclusion}

The results of this study indicate that fears of the fading of cultural heritage that have been predominantly ancestral for decades are not proven. The Gumelem people see opportunities from the new culture promoted by developed countries while still adjusting the attitude of Java. However, the right strategy is still needed so that local culture is not eroded by foreign culture and has the potential to eliminate it. The strategy that can be implemented is the development of identity to strengthen Javanese identity and utilize information technology to introduce local culture to the world community. The revitalization steps undertaken include, among others, using local and national languages which contain specific local values that strengthen national culture.

Looking at the values contained in Sadran actually one value cannot be confused with other values. Because one element in the Sadran tradition can have more than one value where they are interrelated. This paper is not to try to separate, just to sort out so that the context is easier to understand. Maintaining a balance between humans and nature at a normal point will create a harmonious environment. Humans will consciously know the place, so they will also consciously interact with others and the natural environment. This inner attitude can create harmony in human life in maintaining the integrity of nature. Humans will always feel like part of a series of mutually symbiotic life systems, need each other, so that in treating others or the environment will be very careful and polite. Such behavior has been conditioned for generations in such a way as not to damage the cycle of order that already applies so that it is almost There is no conflict either horizontally or vertically. Sadran Gedhe tradition contains three aspects, namely pilgrimage, almsgiving, and a form of gratitude that has socio-cultural, economic, psychological and religious values contained in Javanese philosophy. Also, as a cultural festival that seeks to maintain local culture. By seeing Sadran Gedhe through the perspective of Javanese culture, it can reflect the concept of harmony for a better life while still adjusting the development of the times. The description of Sadran has given birth to a variety of cultural resources and ways of interpretation that complement the spectrum of Javanese culture.

\section{Acknowledgement}

Alhamdulillah, all praises due to Allah, I can finally complete this paper which ia a small part of my research. I would like to acknowledge several peope for the contribution they made to this study. I would also like to apologise to anyone whom I forget to mention here.

First of all, I am grateful to Mora (The Ministry of Religious Affairs) for the doctoral program so that I have the opportunity to study at the doctoral level including doing this research. Without this funding, it would not have been financially possible for me to come to 
study in Universitas Gadjah Mada. I owe great debt to Dr. Bambang Hudayana., M.A. who has been my pricipal supervisor in the Department of Anthropology, Universitas Gadjah Mada. I would like to thank him for his considerable assistance at important moment of my study. My Co- Supervisor on this work, Dr. Setiadi, has also been very helpful to me in many respects. There are too many people in Gumelem to whom I am indebted. Without willingness to spare their time and to share their perceptions with me, it would not have been possible for me to compelete my study. I express my thanks to the family of Ibu Partimah and Ibu Waridah. My deep thanks go to Ibu Warsiyem, Bapak Agus, Bapak Jeri for their deep understanding of Sadran Gedhe Tradition.

\section{Reference}

[1] Wandansari, "Aktualisasi Nilai-Nilai Tradisi Budaya Daerah Sebagai Kearifan Lokal Untuk Memantapkan Jatidiri Bangsa.," 2015.

[2] I. yani Arinda, "Sedekah Bumi (Nyadran) Sebaga Konvensi Tradisi Jawa Dan Islam Masyarakat Sraturejo Bojonegoro," el Harakah, vol. 16, no. 1, p. 103, 2014.

[3] S. Makhmudah, "Mensinergikan Nilai-Nilai Keagamaan dengan Kearifan Lokal sebagai Upaya Mewujudkan Masyarakat Madani (Studi Kasus Komunitas Keagamaan Kejawen di Desa Bajulan Kecamatan Loceret Kabupaten Nganjuk)," J. Konseling dan Pendidik., vol. 5, no. 1, p. 11, 2017.

[4] A. Rachmadhani, U. Suropati, and S. Kav, "Role of W Ali, Ancient Mosque and Sacred Tomb in Islam Spreading," J. Kebud. Islam, vol. 14, no. 2, pp. 226-241, 2016.

[5] A. Basir, "Nilai Pendidikan Islam Dalam Budaya Tenongan Nyadran Suran Di Dusun Giyanti Wonosobo," J. Kependidikan al-Qalam, vol. IX, pp. 69-78, 2013.

[6] W. Setiyani, "Implementasi Psikologi Humanistik Carl Rogers Pada Tradisi Lokal Nyadran Di Jambe Gemarang Kedunggalar Ngawi," Islam. J. Stud. Keislam., vol. 12, no. September, pp. 230 $257,2017$.

[7] W. N. Alifiana, "perubahan Budaya Dalam Tradisi Nyadran di Kelurahan Ngantru Trenggalek," J. Progr. Stud. Pendidik. dan sastra jawa, vol. 2, no. 01, pp. 56-72, 2013.

[8] S. dan M. P. H. Utami, "Tindak Tutur Dalam Tradisi Nyadran (Nglarung Sesaji) Di Dusun Kepetingan Desa Sawohan Kecamatan Buduran Kabupaten Sidoarjo : Kajian Pragmatik," J. Ilm. FONEMA J. Edukasi Bhs. dan Sastra Indones., vol. 1, no. 1, p. 74, 2018.

[9] E. S. I. F. Purwaningsih, Kearifan Lokal Dalam Tradisi Nyadran Masyarakat Sekitar Situs Liangan. Daerah Istimewa Yogyakarta: Kementerian Pendidikan dan Kebudayaan, 2016.

[10] Mumfagati, "Tradisi Ziarah Makam Leluhur Pada Masyarakat Jawa," Jantra, vol. II, no. 3, pp. 152-159, 2007.

[11] C. Guillot, Ziarah dan Wali di Dunia. Jakarta: Komunitas Bambu, 2011.

[12] C. R. . Suyono, Dunia Mistik Orang Jawa: Ruh, Ritual Benda Magis. Yogyakarta: LKis Printing Cemerlang, 2012.

[13] Jamhari, "The Concept of Barakah in Ziarah," Stud. Islam., vol. 8, no. 1, 2001.

[14] Y. N. Sih, K. Saddhono, and B. Setiawan, "Religious Value in Nyadran Ceremony in Ngepringan Village, Sragen," El Harakah, vol. 20, no. 2, p. 155, 2018.

[15] Indrawati, S. Soetomo, B. Setioko, T. W. Murtini, and Nurhasan, "Edu - Religious Tourism Based on Islamic Architecture Approach, a Prelimenary Research in Majasto Cemetery - Sukoharjo Regency Central Java," Procedia - Soc. Behav. Sci., vol. 227, pp. 656-663, 2016.

[16] N. Yunikasari, F. Seni, and R. Dan, "Nyadran dam bagong trenggalek," 2018.

[17] A. Kastolani; Yusof, "Relasi Islam Dan Budaya Lokal," Kontemplasi, vol. 04, no. 01, p. 66, 2016.

[18] J. Ariyanti, "Bentuk Makna Simbolis dan Fungsi Tradisi Nyadran di Desa Kedunglo Kecamatan Kemiri Kabupaten Purworejo," Universitas Muhammadiyah Purworejo, 2016.

[19] S. G. W. P. A. and L. D. W. Winarni, "Akulturasi Budaya Islam Dan Jawa: Ruang Komunal pada Budaya Nyadran Dukuh Krajan, Desa Kromengan, Kabupaten Malang," El-Harakah, vol. 15, no. $1,2013$. 
[20] D. Daryono, "Berbagai Berkah Bid'Ah Nyadran Dalam Budaya Islam Jawa,” J. Din. Sos. Budaya, vol. 19, no. 2, pp. 209-220, 2017.

[21] A. Ali, Sosiologi Pendidikan dan Dakwah. Cirebon: Stain Press, 2007.

[22] H. Ibda and J. Tengah, "Penguatan Nilai-Nilai Sufisme Dalam," vol. 02, no. 02, pp. 148-161, 2018.

[23] E. Suryanti, Antisipasi Strategis Perang Nilai Budaya Lokal di Area Global. Yogyakarta: Bappeda Provinsi DIY, 2007.

[24] E. Santosa, "Strategi Pendidikan Bahasa, Sastra, Budaya di Sekolah dan Masyarakat Melalui Tradisi Kebudayaan," 2015.

[25] H. S. Ahimsa, Ketika Orang Jawa Nyeni. Yogyakarta: Galang Press, 2006.

[26] dan T. B. P. Darisma, Nuryani Siti , I wayan Midhio, "Aktualisasi nilai-nilai tradisi nyadran sebagai kearifan lokal dalam membangun budaya damai di giyanti, wonosobo the actualization of nyadran tradition as local genius in peace culture building in giyanti, wonosobo," vol. Volume 4 (, no. Jurnal Prodi Damai dan Resolusi Konflik, pp. 21-44, 2018.

[27] L. Neuman, Metode Penelitian Sosial: Pendekatan Kualitatif Kuantitatif. Jakarta: Permata Puri Media, 2013.

[28] S. Endraswara, Agama Jawa Ajaran, Amalan dan Asal Usul Kejawen. Yogyakarta: Narasi, 2015.

[29] S. dan A. B. Ningsih, "Pituduh Jawa: Jawanisasi Orang Jawa," 2015.

[30] S. Endraswara, Mistik Kejawen. Yogyakarta: Narasi, 2006.

[31] T. Daniels, Islamic Spctrum In Java. 2019.

[32] A. Abbas, "Kesejian Ojhung dalam Tradisi Sedekah Bumi di Desa Bunbarat Kecamatan Rubaru Kabupaten Sumenep," Avatara e-Jurnal Pendidik. Sej., vol. 5, no. 1, pp. 81-90, 2017.

[33] D. A. Satria, "Nilai dan Fungsi Dalam Tradisi Nyadran di Padukuhan Gejayan, Condongcatur, Depok, Kabupaten Sleman," Universitas Islam Negeri SUnan Kalijaga Yogyakarta, 2017.

[34] A. Riyadi, "Kearifan Lokal Tradisi Nyadran Lintas Agama di Desa Kayen-Juwangi Kabupaten Boyolali," Smart, vol. 03, pp. 139-154, 2017.

[35] E. Durkheim, Suicide: A Study in Sociology. New York: The Press, 1966. 